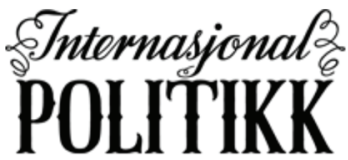 \\ SKANDINAVISK TIDSSKRIFT \\ FOR INTERNASIONALE STUDIER
}

Årgang 78, Nummer 3, side 233-256, 2020, ISSN 1891-1757, www.tidsskriftet-ip.no, Publisert september 2020

\section{Færøernes militærgeografiske betydning for USA og NATO}

\author{
Esben Salling Larsen \\ Forsvarsakademiet, Danmark
}

\begin{abstract}
Sammendrag
I litteraturen om Danmark under Den Kolde Krig og om Færøsk sikkerhedspolitik finder man argumentet om, at flere militære installationer gav Færøerne en særlig strategisk betydning i NATO under Den Kolde Krig. Denne artikel har analyseret Færøernes betydning i et militærgeografisk perspektiv og har anvendt et bredere kildegrundlag end den hidtidige litteratur og har sammenlignet med andre tilsvarende beliggenheder. På den baggrund kan det konkluderes, at Færøerne har været en dominerende geografisk position i en kort periode i 1960'erne. Modsat den gængse fremstilling i eksisterende dansk og færøsk litteratur på området var Færøerne ikke et betydende baseområde under Den Kolde Krig, og de tekniske installationer var ikke unikke, men udtryk for, at der under Den Kolde Krig etableredes talrige tilsvarende installationer. Færøernes militære betydning under Den Kolde Krig kan ses som en forståelsesramme for Færøernes fremtidige betydning. På den baggrund bør man tage udgangspunkt i, hvordan Færøernes beliggenhed konkret kan understøtte militære operationer, og man skal gøre sig klart, at en ny sikkerhedspolitisk situation ikke nødvendigvis giver områder som Færøerne en blivende betydning, men sagtens kan medføre en vekslende betydning.
\end{abstract}

Nøgleord: Militærgeografi • Færøerne · Kold krig • NATO • Nordatlanten

\footnotetext{
^Kontaktinformasjon: Esben Salling Larsen, e-post: esla@fak.dk

(C)2020 Esben Salling Larsen. This is an Open Access article distributed under the terms of the Creative Commons Attribution 4.0 International License (http://creativecommons.org/licenses/by/4.0/), allowing third parties to copy and redistribute the material in any medium or format and to remix, transform, and build upon the material for any purpose, even commercially, provided the original work is properly cited and states its license.

Citation: Esben Salling Larsen (2020). Ferøernes militergeografiske betydning for USA og NATO. Internasjonal Politikk, 78(3): 233-256. http://dx.doi.org/10.23865/intpol.v78.1807
} 


\section{Indledning}

Arktis er genstand for en fornyet geopolitisk interesse, herunder en forøget amerikansk opmærksomhed, og inden for Kongeriget Danmark ${ }^{1}$ ses Færøerne og Grønland at have en stigende strategisk betydning (Krog, 2019). Færøernes kontinentalsokkel strækker sig nord over polarcirklen, og Færøernes selvstyre ser Færøerne som en vigtig del af Arktis og af en arktisk strategi for Kongeriget Danmark (Statsministeriet, 2020). Færøske interesser er her ikke nødvendigvis sammenfaldende med danske eller amerikanske interesser, hvilket blandt andet blev eksemplificeret, da en kinesisk udbyder stod til at skulle levere 5G mobilnetværk til Færøerne, og hvor der var stort pres på Færøerne om ikke at vælge denne udbyder af sikkerhedspolitiske hensyn (Nielsen, 2020; Breum, 2019). Den færøske lagmand Bárður á Steig Nielsen udtalte i 2019, at "Ferøernes strategiske placering $i$ Nordatlanten giver os nye muligheder" (Statsministeriet, 2020). Det bygger blandt andet på en antagelse om, at USA har en strategisk interesse i Færøerne, på samme måde som USA har en strategisk interesse i Grønland (Rigsombudsmanden, 2020, s. 5). Dette trækker tråde tilbage til en fortælling om, at Færøerne var vigtig for USA under Den Kolde Krig og udgjorde dermed et aktiv for Danmark (Johansen, 1999; Jensen, 2004). Denne artikel undersøger Færøernes militære betydning for USA under Den Kolde Krig. Den historiske ramme er på mange måder en forståelsesramme for debatten mellem Danmark og Færøerne (Bertelsen, 2019). Derfor har det betydning, hvilken militær betydning Færøerne havde under Den Kolde Krig. Færøerne kan desuden som case anvendes til at sige noget om, hvordan en bestemt geografisk placering kan have strategisk betydning. En analyse af Færøernes betydning under Den Kolde Krig giver derfor ikke alene en ramme for at forstå Færøernes fremtidige betydning, men også en ramme for at forstå nutidig militær-strategisk betydning af andre områder i Arktis og Nordatlanten. Vil man sige noget mere generelt om militær betydning af småstaters territorier og have en forståelsesramme for Færøernes betydning i den fremtidige udvikling, er der derfor grund til at se på Færøernes betydning under Den Kolde Krig. Artiklen vil derfor se på, om Færøerne var en geografisk dominerende position for Danmark og allieredes militære operationer under Den Kolde Krig. Artiklen gennemgår indledningsvist de overordnede argumenter i den eksisterende litteratur om Færøernes militære betydning under Den Kolde Krig. Derefter beskrives, hvordan man kan analysere militær betydning af et geografisk område eller placering. Med udgangspunkt i den eksisterende litteratur undersøges militærgeografiske forhold, der kan lægges til grund for Færøernes militære betydning og der foretages en analyse af sammenhængen mellem de installationer og beliggenheder, der hidtil har begrundet militær betydning og konkrete militære operationer. Herunder undersøges om de pågældende installationer og beliggenheder også set $i$ et bredere militært og alliancemæssigt perspektiv kan betegnes som dominerende geografiske positioner med en særlig militær betydning.

\footnotetext{
${ }^{1}$ Kongeriget Danmark anvendes som samlende betegnelse for Danmark, Grønland og Færøerne.
} 
Militær betydning analyseres ved at se på de handlemuligheder, som beliggenhed på Færøerne gav NATO's og USA's strategi og militære operationer, samt i hvilket omfang Færøernes beliggenhed gav specielle og unikke militærgeografiske handlemuligheder. For hver af de analyserede installationer og beliggenheder konkluderes der på militær betydning under Den Kolde Krig. De installationer og beliggenheder, der undersøges, er Færøernes generelle rolle som baseområde, herunder den risiko en modstanders besiddelse af Færøerne potentielt kunne udgøre, samt de specifikke installationer som er nævnt i den eksisterende litteratur. Der konkluderes samlet på Færøernes militære betydning under Den Kolde Krig og der perspektiveres på Færøernes betydning under Den Kolde Krig som en fremtidig forståelsesramme for militær betydning.

\section{Den eksisterende litteratur om Færøernes militære betydning under Den Kolde Krig}

I den danske og færøske litteratur om Den Kolde Krig er der en udbredt konsensus om, at Færøerne og dets geografiske placering var en fordel i Danmarks forhold til USA og NATO. To officielle færøske historiske undersøgelser har undersøgt Færøernes strategiske betydning under Den Kolde Krig (Johansen, 1999; Jensen, 2004). Begge konkluderer, at Færøerne var et aktiv for Danmark i forhandlinger med NATO og USA. I dele af litteraturen finder man argumentet om danske fordele (eksempelvis lavere forsvarsbudgetter) ved at give allierede adgang til Færøerne (Jácobsstovu \& Berg, 2012; Jensen, 2014a, s. 66-68; Villaume, 1995, s. 616-621).

Den militære betydning af Færøerne og Grønland har også været en del af debatten om selvstændighed for de to områder. Modsat andre nordiske lande er den militære betydning af områder i Kongeriget Danmark ikke kun et anliggende mellem staten og dens allierede, men også et anliggende internt mellem de forskellige rigsdele (eller nationer) i Kongeriget Danmark. Når flere kilder betoner økonomiske fordele ved, at Færøerne husede militære installationer, så handler det også om færøsk selvstændighed, herunder muligheden for økonomisk uafhængighed fra Danmark (Jácobsstovu \& Berg, 2012; Johansen, 1999, s. 44; Johansen, 2011). I forlængelse af den officielle færøske undersøgelse af Færøernes betydning i 1999 var der en debat mellem Færøerne og Danmark (Johansen, 1999; Brøndum, 2000). Her argumenterede den daværende færøske lagmand for selvstændighed for, at Færøerne ved selvstændighed skulle have en god økonomisk overgangsordning med Danmark, begrundet i en rabat som Danmark skulle have opnået i NATO ved at stille Færøerne til rådighed for militære installationer (Brøndum, 2000). Det førte til en skarp brevveksling mellem den danske statsminister og den færøske lagmand om Færøernes forsvarsmæssige betydning (Brøndum, 2000). Dermed blev spørgsmålet om militær betydning set i sammenhæng med spørgsmålet om færøsk selvstændighed, og hemmeligholdelse af militære oplysninger blev set $i$ lyset af at ville skjule militær betydning og dermed økonomisk værdi. 
I den eksisterende litteratur er de geopolitiske omstændigheder rammen om Færøernes betydning, hvor Danmark får en fordel, fordi USA og NATO har brug for en beliggenhed på Færøerne til et bestemt militært formål. Men der er et fravær af referencer til alliancedynamikker og teorier i den eksisterende litteratur, hvilket er interessant, da den gængse antagelse i allianceteorier ellers er, at mindre stater under alle omstændigheder vil kunne slippe billigere end større allierede (Keohane, 1971; Snyder, 1984; Walt, 1985; Ringsmose, 2010; Plümper \& Neumayer, 2015). Danmarks forsvarsudgifter under Den Kolde Krig lå i den lave ende målt i forhold til bruttonationalproduktet. Men det kan ikke i sig selv dokumentere, at Danmark havde geografiske områder med en særlig betydning, der gav rabat i alliancesammenhæng. Man skulle i givet fald dokumentere, at Danmark fik en ekstraordinær rabat, hvilket er svært at påvise i praksis. I stedet kan man vælge at se på den konkrete militære værdi og dermed tage et militærgeografisk udgangspunkt. Det er det, som denne artikel vil gøre. Militærgeografi bliver i denne sammenhæng defineret som studiet af, hvordan militarisme og militære aktiviteter er geografisk konstitueret og kommer til udtryk (Woodward, 2016, s. 1). Den eksisterende litteraturs fokus på det dansk-færøske forhold betyder samtidig et fravær af sammenligning med andre tilsvarende allierede stater og beliggenheder. Når alliancedynamikker implicit lægges til grund for Færøernes betydning under Den Kolde Krig, kan en sammenligning med andre placeringer og stater tilføje en væsentlig dimension. Den nuværende litteraturs vinkel er dog ikke usædvanlig, idet der i nordisk koldkrigsforskning er en mangel på komparative studier af koldkrigspolicy og erfaringer mellem de nordiske lande (Olesen, 2008, s. 195). Denne artikel sammenligner med primært Island, der er interessant, fordi Færøerne og Island potentielt er militærgeografiske alternativer og dermed konkurrenter om allieret interesse.

Den eksisterende litteratur har ofte en detaljeret gennemgang af specifikke militære forhold. Eksempelvis et radiofyr (Villaume, 1995, s. 853), en radarstation (Johansen, 1999, s. 40) eller en ankerplads for et depotskib (Jensen, 2004, s. 193). De sættes $\mathrm{i}$ en politisk ramme, men sjældent $\mathrm{i}$ en operativ sammenhæng eller $\mathrm{i}$ en teoretisk geopolitisk ramme, idet en af de få eksplicitte referencer til en teoretisk forståelsesramme for de geopolitiske forudsætninger for Færøernes militære betydning er en reference til Mackinders Heartland/Rimland teori (Tamnes, 1991, citeret i Johansen, 1999). Den militære aktivitet er derfor på den ene side meget veldokumenteret i litteraturen, men på den anden side går analyserne i den eksisterende litteratur typisk direkte fra en konkret militær aktivitet over i en antagelse om strategisk betydning byggende på politiske forhold, uden at denne sammenhæng nødvendigvis er underbygget. Denne artikel vil derfor i stedet tage udgangspunkt i de konkrete militære aktiviteter og operationer og analysere disses sammenhæng på operativt niveau for at kunne konkludere på den strategiske betydning.

Dele af den eksisterende litteratur er skrevet på et tidspunkt, hvor adgangen til relevante arkiver var mere begrænset, end tilfældet er i dag. Skal man sætte Færøerne i en militær-strategisk sammenhæng, er det hensigtsmæssigt at have adgang 
til militære kilder, samt anden litterattur der baserer sig på militære kilder, der kan fortælle noget om de militære hensigter og de operationer, som installationerne på Færøerne understøttede og indgik i. Relevant arkivmateriale er frigivet efter udgivelsen af centrale dele af litteraturen. Især NATO's arkiver er åbnet op. Denne artikel vil derfor supplere med nye primære kilder fra NATO's arkiver og det amerikanske forsvars arkiver samt nyere sekundære kilder om tekniske og militære forhold, der er baseret på en nyere og bredere kildeadgang.

Den eksisterende litteratur har en grundig gennemgang af primære historiske kilder fra det amerikanske udenrigsministerium, Udenrigsministeriet, Forsvarsministeriet samt i nogen grad det færøske lagtingstidende. Når sagens kerne i Færøernes militære betydning ofte er den militær-strategiske betydning af tekniske anlæg, kan anvendelsen af ministerielle kilder, hvor der nogle gange er tale om vurderinger, på nogle områder kun give et delvist billede. Man er afhængig af, at eksempelvis en amerikansk embedsmand har forstået den tekniske sammenhæng i det, vedkommende formidler, samt at den danske embedsmand omvendt forstår den tekniske sammenhæng tilstrækkeligt til at videreformidle den korrekt. Den eksisterende litteratur giver et godt udgangspunkt for at genbesøge Færøernes militære betydning under Den Kolde Krig, men suppleres i denne artikel med andre perspektiver og kilder for at sætte Færøerne ind i en større alliancesammenhæng og for bedre at forstå de militære hensigter i relation til Færøerne.

\section{Hvordan kan man analysere Færøernes militære betydning?}

Skal man se på det militære rationale bag at placere særlige militære installationer på Færøerne, kan man anvende en militærgeografisk forståelsesramme. Militærgeografi drejer sig om, hvordan geografiske faktorer påvirker militære handlemuligheder og strategier, og hvordan man militært ser disse muligheder (Woodward, 2016). Militærgeografi har traditionelt handlet om terræn og taktik; bogstaveligt talt om slagmarken (Woodward, 2016, s. 2-3). En bredere forståelse af militærgeografi omfatter den indflydelse, som de fysiske og kulturelle omgivelser har på politisk-militære politikker, planer, programmer og operationer i alle typer af globale, regionale og lokale sammenhænge (Collins, 1998, s. 3-7). Militærgeografien er foranderlig og vil ændre sig i takt med den militærteknologiske udvikling og de rivaliserende parter. Militærgeografien drejer sig om militære handlemuligheder, der igen drejer sig om opfattelser af hensigt og af, hvad der er muligt (Gray 2012, s. 301-302).

Der er mange mulige geografiske faktorer, og der kan ikke gives en fast model for, hvordan man tilgår militærgeografien (Collins, 1998). En metodisk tilgang er derfor at identificere hvilke fysiske og kulturelle geografiske faktorer, der er i spil, og på den baggrund se på militære handlemuligheder ud fra den logik, der følger med de pågældende militærgeografiske faktorer. De militærgeografiske faktorer, der er i spil i Færøernes tilfælde, handler primært om spatialitet; at forskellige geografiske beliggenheders relative placering kan gøre én beliggenhed mere betydningsfuld end 
en anden (Collins, 1998, s. 11-15). Man kan tale om dominerende geografiske positioner, hvorfra man bedst kan opnå militære mål (Collins, 1998, s. 15). De er dominerende i kraft af deres relative placering i forhold til andre placeringer og på baggrund af parternes potentielle militære brug af positionen. For at undersøge om Færøerne havde en særlig militær betydning, skal man således undersøge om Færøerne, eller en militær installation på Færøerne, kan betegnes som en dominerende geografisk position.

Geografiske faktorer giver kun mening militært, når de relateres til deres mulige påvirkning af egne og modstanderens handlemuligheder (Collins, 1998, s. 3-8). De tre radarpositioner for USA's varsling mod interkontinentale atommissiler i Alaska, Grønland og Storbritannien kan eksempelvis betegnes som dominerende positioner, fordi de gør det muligt for USA at opnå en strategisk vigtig varsling, som USA ikke har uden disse positioner (Collins, 1998, s. 16). Teknologien er også en faktor for dominerende positioner. Lufthavnene i Goose Bay i Canada og Keflavik på Island var eksempelvis forudsætningen for, at de allierede under anden verdenskrig kunne færgeflyve datidens fly over Atlanten med tilstrækkelige mellemlandinger (Collins, 1998, s. 16). Betydningen er også kontekstuel. Eksempelvis er USA's adgang til Azorerne af militær-strategisk betydning, men havde en særlig betydning i forbindelse USA's luftbro til Israel i 1973, hvor mange europæiske lande ikke ville understøtte luftbroen (Collins, 1998, s. 16). Dominerende geografiske positioner er således steder, hvorfra man, givet den anvendte teknologi, og givet de mulige alternative geografiske muligheder, bedst kan gennemføre specifikke militære aktiviteter. Dominerende geografiske positioner kan findes fra det strategiske niveau og ned til taktiske styrkers konkrete opgaveløsning.

Denne artikel vil undersøge, om Færøerne, og flere forskellige beliggenheder på øerne, kan betegnes som militærgeografisk dominerende. Konkret vil den gøre det ved at se på, om 1) Færøerne var en hensigtsmæssig placering for det tekniske anlæg eller baseområdet, givet de operationer og den tekniske løsning som placeringen på Færøerne skulle understøtte, og 2) om Færøerne var en unik mulighed for placering eller en mere betydningsfuld beliggenhed end andre tilsvarende beliggenheder for anlæg eller baseområder. Færøerne kan ses i såvel et allianceperspektiv som i et modstanderperspektiv, og denne artikel vil undersøge begge perspektiver. Når betydning ses $\mathrm{i}$ forhold til hensigt og opfattelse af, hvad der er muligt, kan samme område have forskellig betydning for partnerne (Gray 2012, s. 301-302). Denne artikel vil også se på, hvordan NATO så Færøerne som en mulig sovjetisk dominerende geografisk position i tilfælde af krig. Den vil tage udgangspunkt i de miltære formål og installationer, der er beskrevet i den nuværende litteratur, og undersøge, hvorvidt disse udgjorde en dominerende geografisk position i militærgeografisk sammenhæng. Det drejer sig om Færøerne som baseområde (Villaume, 1995, s. 616-621; Johansen, 1999, 2011; Jensen, 2004), Loran-C radiofyret i Eiði (Villaume, 1995, s. 853; Johansen, 1999; Johansen, 2011; Jensen, 2014a), Radarstationen på Sornfelli (Johansen, 1999, s. 40; Jensen, 2014a, s. 70; Olesen \& Villaume, 
2018, s. 301) samt troposfære kommunikationssystemer (Johansen, 1999, s. 44; Jensen, 2004, s. 201-202).

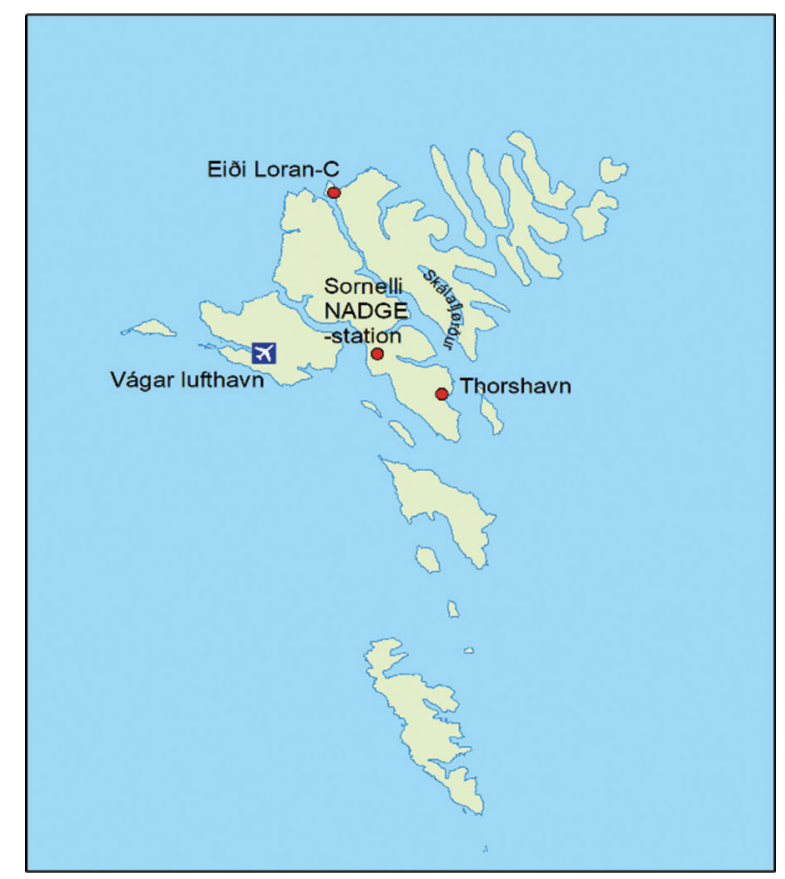

Figur 1. Installationerne på Færøerne.

\section{Færøerne som baseområde}

Dele af litteraturen beskriver generelt Færøerne som et interessant baseområde (Villaume, 1995, s. 616-621; Johansen, 2011; Jensen, 2004). Et sted beskrives Færøerne som et velegnet baseområde, der lå godt for kontrollen med trafik til søs og i luften med en placering tæt på farvandet mellem Grønland, Island og Storbritannien - det såkaldte GIUK-gab ${ }^{2}$ (Jensen, 2014a, s. 66-67). Andre argumenterer for, at selvom øerne var placeret tæt på GIUK, så var Færøernes betydning marginal, selvom Færøerne muligvis blev relativt vigtigere i Danmarks bidrag til NATO's afskrækkelse undervejs i Den Kolde Krig (Faurby \& Petersen, 1988, s. 8-9 \& s. 22-23).

Færøerne havde begrænsede muligheder for større militær anvendelse, men havde dog gode havne og ankerpladser. Konkret efterspurgte NATO adgang til basefaciliteter i form af ankerpladser i Skálafjørður og adgang til Vágar lufthavn ${ }^{3}$ som nødlandingsplads for NATO fly (Jensen, 2004, s. 193; NATO, 1953). Skálafjørður

\footnotetext{
${ }^{2}$ Greenland-Iceland-United Kingdom (GIUK).

${ }^{3}$ Der blev vurderet begrænset med hensyn til landingsbane og fremherskende vejrlig (NATO, 1953).
} 
var under Anden Verdenskrig en beskyttet ankerplads for britiske forsynings- og tankskibe, og NATO's planer var, at depotskibe kunne deployere til Skálafjørður og ankre op i fjorden, hvor depotskibene kunne fungere som en alternativ basemulighed for blandt andet atomubåde (Jensen, 2014b).

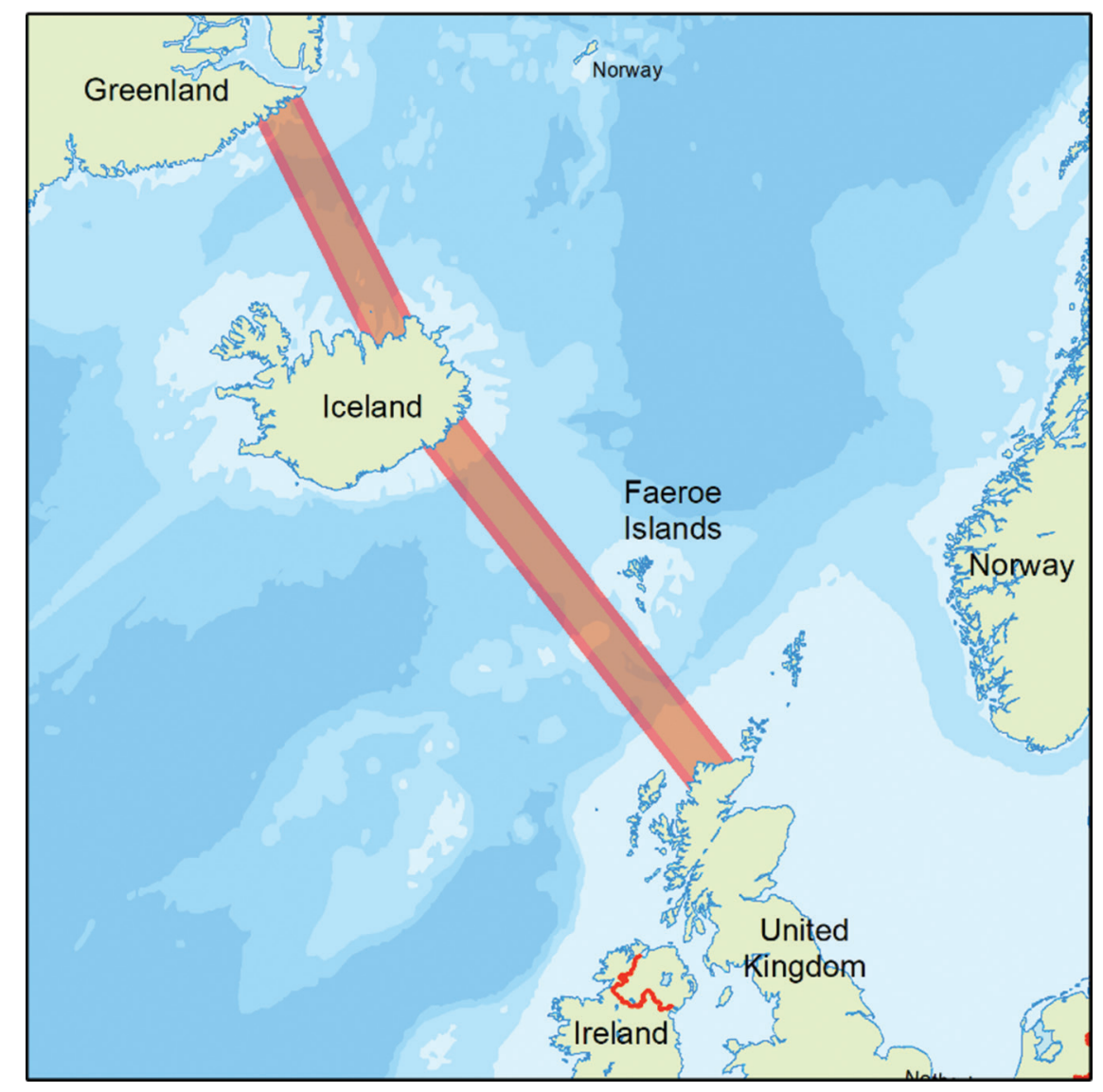

Figur 2. GIUK Gap.

De militære operationer under Den Kolde Krig, som Færøerne potentielt kunne understøtte som baseområde, omfattede USA's og NATO's operationer i GIUK og Norskehavet. Fra starten af Den Kolde Krig og frem til 1960'erne skulle NATO's transatlantiske forsyningslinjer beskyttes mod sovjetiske konventionelle ubåde (Grygiel, 2005, s. 197-199). Færøernes rolle i den forbindelse var beskeden, hvilket fremgår af den danske militære ledelses tidlige drøftelser med NATO (NATO, 1953). NATO's operationer i det nordøstlige Atlanterhav ændrede karakter i 1960'erne med introduktionen af atomubåde og atommissiler. Med fremkomsten af sovjetiske missil-atomubåde fra midten af 1960'erne blev Norskehavet et vigtigt område for NATO's flerværnsoperationer, og tilsvarende blev GIUK et spærreområde for 
russiske ubådes adgang til operationsområderne for USA's missil-atomubåde i det vestlige Atlanterhav (Dyndal, 2011). Norskehavet var et selvstændigt operationsområde i NATO, hvor der fra slutningen af 1970'erne var fokus på såvel flådeoperationer som taktiske flyoperationer (Skogrand, 1998, s. 7-8). NATO's forsvar mod fjendtlige ubåde i GIUK var et lagdelt forsvar, hvor ubåde og maritime patruljefly opererede fremskudt mod nord, og ubåde opererede i GIUK strædeområderne (Grove, 1989, s. 4-6). Fra 1969 bestod NATO's antiubåds-operationer i stigende omfang af bælter af langtrækkende maritime patruljefly (Kochis \& Slattery, 2016, s. 4).

Sammenligner man Færøerne med Island finder man, at Island havde en langt mere fremtrædende placering under Den Kolde Krig. Ved starten af Den Kolde Krig blev Island udnævnt til et af seks vigtige baseområder af USA (DUPI, 1997, s. 54). I senere NATO-strategier nævnes Island sammen med Grønland, som vigtige områder under NATO's Atlanterhavskommando (NATO, 1969a, s. 13). ${ }^{4}$ Centralt for Islands betydning var Keflavik flybase, som USA oprettede under 2. verdenskrig som en af sine største flybaser (Benediktsson, 2011). Island fik en større rolle i 1960 'erne med bl.a. permanent stationerede maritime patruljefly og en Sound Surveillance System (SOSUS) ${ }^{5}$ station på Keflavik (Benediktsson, 2011). Island fik derfor en mere fremtrædende rolle som baseområde, fordi Island husede egentlige amerikanske baser med direkte betydning for USA's og NATO's militære operationer under Den Kolde Krig.

Island truede flere gange under Den Kolde Krig med at forlade NATO, eller at fjerne adgangen til baser, hvilket i sidste halvdel af 1950'erne og i midten af 1970'erne tvang USA og NATO til at overveje deres muligheder (Ingimundarson, 1999, 2003). I 1950'erne så NATO fire strategiske, militære konsekvenser ved et bortfald af adgang til baser på Island (NATO, 1956a, 1956b, 1956c). For det første ville et vigtigt led i flyvarslingskæden for USA forsvinde. For det andet ville NATO miste en vigtig base for anti-ubådsstyrker. For det tredje ville NATO miste en fremskudt forsyningsbase og understøttelsen af maritim tilstedeværelse i vigtige områder. For det fjerde ville NATO miste et vigtigt knudepunkt for kampfly-forstærkningsstyrker til Europa. I 1970'erne var der forhandlinger mellem USA og Island om baser (Ingimundarson, 2003, s. 108-109). Her kom det frem, at NATO's øverstbefalende i Atlanterhavet (SACLANT) vurderede det i teorien muligt, men i praksis tidskrævende og kostbart, at flytte baser og installationer til Skotland, samt at fraværet af en base på Island ville reducere den amerikanske evne til at monitorere de sovjetiske ubåde (Ingimundarson, 2003, s. 108-109). Det fortæller os, at NATO og USA ikke blot anså Island som meget betydningsfuld for vigtige militære operationer, men også at de vurderede, at der ikke var reelle alternativer til Island.

\footnotetext{
${ }^{4}$ Færøerne nævntes ikke i den forbindelse.

${ }^{5}$ Ubåds-overvågningssystem med sensorer på havbunden.
} 
Ved starten af Den Kolde Krig havde farvandet omkring Færøerne stor betydning, og det fik større betydning fra midten af 1960'erne med fremkomsten af atommissiler og atomubåde. Færøerne kunne således potentielt have været en hensigtsmæssig placering for et baseområde givet de militære operationer, som NATO og USA planlagde. Omvendt er det bemærkelsesværdigt, at NATO alene planlagde at anvende Færøerne som base i en sekundær sammenhæng - som alternativ landeplads, hvis fly kom i problemer, eller som ankerplads for depotskibe, hvis der blev behov for at sprede logistikken ud fra de primære baser til støtte for atomubåde. Som baseområde havde Færøerne således en relativt mindre betydning under Den Kolde Krig end under Anden Verdenskrig, hvor Færøerne havde været et beskyttet baseområde. I den forbindelse kan våbenteknologien have en betydning. Blandt andet betyder den forøgede vægtning af maritime patruljefly i NATO's og USA's operationer fra slutning af 1960'erne, at Færøerne, med sin begrænsede lufthavn, ikke kunne understøtte vigtige elementer i operationerne. Det er også bemærkelsesværdigt, at når NATO så på alternativer til baserne på Island i forbindelse med islandske trusler om at fjerne adgangen til baser, så er det muligheder i Skotland, der overvejes. Færøerne bringes ikke i spil som en reel mulighed og det kan på den baggrund konkluderes, at Færøerne ikke var velegnet som baseområde for NATO's og USA's operationer i området. Færøerne gav ikke de muligheder, som Skotland, og især Island, gav rent militærgeografisk.

Når man skal forstå, om Færøerne havde en unik eller særlig betydningsfuld militærgeografisk placering sammenlignet med andre, så er Islands betydning helt central. Med den betydelige opbygning af basefaciliteter, der fandt sted under Den Kolde Krig, kan Island, især som base for anti-ubådsstyrker, betegnes som en dominerende geografisk placering. Det understreges af NATO's og USA's vurderinger af Islands betydning, når Island under Den Kolde Krig truer med at trække sig fra NATO og baseaftaler. Samlet set må Island derfor vurderes som langt mere velegnet end Færøerne som baseområde. Udviklingen i de militære operationer betyder også, at fokus for NATO's operationer fra midten af 1960'erne forskydes mod nord og dermed tættere på Norge og Island. Man kan derfor, i et sammenlignende perspektiv, ikke betegne Færøerne som baseområde som en militærgeografisk dominerende position under Den Kolde Krig.

\section{Færøernes potentielle betydning for en modstander}

Hvor den eksisterende litteratur primært ser Færøernes militære betydning i forhold til allierede, så kan betydningen også ses i et modstanderperspektiv. Når Briterne okkuperede Færøerne under Anden Verdenskrig, var det fordi, de frygtede, at tyskerne skulle sætte sig på øerne (Faurby \& Petersen 1988, s. 8). Noget tilsvarende var også et tema under Den Kolde Krig (Johansen, 1999, s. 24-25). I starten af Den Kolde Krig opfattedes den direkte trussel mod færøsk territorium som begrænset og som en trussel, der kunne imødegås gennem oprettelsen af et færøsk 
hjemmeværn $^{6}$ (NATO, 1953, s. 3). Man frygtede, at civile sovjetiske skibe, herunder fiskeskibe, potentielt kunne være udgangspunkt for isolerede angreb. Danmarks øverste militære ledelse anså det for muligt, at Sovjetunionen i det nordlige Atlanterhav kunne foretage luftangreb og mindre specialoperationer landsat med ubåde (NATO, 1953, s. 3). I 1960'erne iværksatte NATO en studie af sovjetisk maritim kapabilitet og strategier, den såkaldte Brosio-studie (Dyndal, 2011, s. 575-580). På baggrund af studien vurderede NATO's militærkomite, at NATO fortsat havde en maritim overlegenhed, der dog i stigende omfang var udfordret af sovjetisk ubådskapacitet (NATO, 1969b, s. 3). NATO's overordnede militære strategi i det atlantiske ansvarsområde var at forsvare sine installationer på øer og sit territorium ved at etablere et fremskudt forsvar til søs samt at gennemføre amfibieoperationer for at sikre, eller generobre, strategiske positioner (NATO, 1969a, s. 24). NATO's militære strategi tog udgangspunkt $i$, at Sovjetunionen i tid og rum kunne gennemføre isolerede operationer, som NATO kunne imødegå med egne amfibieoperationer (NATO, 1969a, s. 24). Det var ikke den danske vurdering, at Færøerne ville blive erobret, snarere ville tekniske installationer blive angrebet fra luften (DIIS, 2005, s. 548). Danmark havde da også et meget begrænset landmilitært forsvar af Færøerne (Jensen, 2014a, s. 64). Udsigterne til at Sovjetunionen kunne udnytte Færøerne som baseområde, var begrænsede, og USA's og NATO's bekymring gik snarere på, at civile sovjetiske skibe og trawlere på Færøerne kunne anvendes til efterretningsindhentning og sabotage mod de tekniske installationer (Jensen, 2004, s. 37).

De planer og forberedelser, der fremgår af NATO-kilderne, viser implicit, at Kongeriget Danmarks allierede reelt beskyttede Færøerne med sine fly-, flåde- og amfibiestyrker. Dermed var præpositionerede styrker på færøsk territorium ikke en forudsætning for, at USA og NATO kunne hindre Sovjetunionen at udnytte Færøerne som fremskudt baseområde/forpost. NATO's strategi om fremskudt forsvar i Atlanterhavet betød også, at NATO og USA med nogen ret også kunne se mange af de aktiviteter, som de tekniske installationer på Færøerne understøttede, som en del af det direkte forsvar af Færøerne.

Det fremskudte forsvar viser også, at Færøerne i stort omfang var beskyttet af lang afstand til de sovjetiske baser samt NATO's maritime overlegenhed i området. Selvom Færøerne lå $\mathrm{i}$ et vigtigt farvand og potentielt kunne have været interessant som sovjetisk forpost, så skal man militærgeografisk tage den samlede spatialitet i betragtning, herunder Færøernes relative placering i forhold til sovjetiske baser (Collins, 1998, s. 11-15). Rent hypotetisk ville sovjetiske kommunikationslinjer til Færøerne have gået forbi et for dem fjendtligt norsk territorium, samt gennem et farvand og et luftrum hvor NATO vurderedes overlegne. Som fremskudt baseområde kunne Færøerne derfor heller ikke i modstander-perspektiv betegnes som en militærgeografisk dominerende position under Den Kolde Krig. Afstanden til Sovjetiske

\footnotetext{
${ }^{6}$ Planerne om et færøsk hjemmeværn blev dog aldrig realiseret (Jensen, 2014a, s. 64).
} 
baser og NATO's maritime overlegenhed på havoverfladen beskytterede i praksis Færøerne mod landmilitære angreb.

\section{Loran-C radiofyret i Eiði}

Den eksisterende litteratur beskriver Færøerne som et sted med gode placeringsmuligheder for kommunikations- og overvågningsanlæg (Faurby \& Petersen, 1988, s. 22-23). Et anlæg, som den eksisterende litteratur tildeler en central rolle i Færøerne betydning, er Loran-C radiofyret $^{7}$ (Villaume, 1995, s. 853; Johansen, 1999, s. 19-30; Johansen, 2011; Jensen, 2014a). Der er to argumenter i litteraturen for, hvorfor Loran-C radiofyret i Eiði gav Færøerne en særlig betydning. Det første handler om, at radiofyret i kraft af sin funktion og placering var vigtigt for de amerikanske Polaris-atomubåde og amerikansk nuklear strategi (Villaume 1995, s. 853; Johansen, 1999, s. 41-42). Det andet er en tese om, at dansk accept af Loran-C i Eiði medvirkede til at svække et amerikansk ønske om at stationere mellemdistanceraketter og taktiske atomvåben i selve Danmark (Villaume, 1995, s. 621).

Argumentet om Loran-C radiofyrets tekniske betydning for Polaris-ubådene bygger på ubådenes strategiske betydning i USA's atomare afskrækkelse (Villaume, 1995, s. 616-621; Johansen, 1999, s. 20-21). Det er derfor den rent tekniske understøttelse af Polaris-ubådenes operationer, der kunne betinge den militære betydning, og Loran-C i Eiði var derfor vigtig, såfremt radiofyret var en afgørende forudsætning for ubådenes militære operationer. Præcist kendskab til ubådens position er en forudsætning for at kunne ramme præcist med ballistiske missiler og en forudsætning for at kunne gemme ubåden i den undersøiske topografi. Kernen i Polaris-ubådenes navigation var et inertinavigationssystem ${ }^{8}$ - det såkaldte Ship's Inertial Navigation System - SINS (Clautice, 1978, s. 36; Refuto, 2011, s. 146). SINS blev upræcist over tid og skulle regelmæssigt have et såkaldt position fix - en ny præcis position som udgangspunkt for den videre navigationsberegning - for at fungere optimalt (Mackenzie \& Spinardi, 1988, s. 431). Loran-C kunne give denne opdatering, hvilket dog forudsatte, at ubåden gik tættere på overfladen (Refuto, 2011, s. 149). Position fix kunne skaffes med andre systemer end Loran-C, eksempelvis med avancerede periskoper eller akustisk aflæsning af havbunden, der dog eksponerede ubåden overfor modstanderens anti-ubådsenheder (Ball, 1977, s. 28; MacKenzie \& Spinardi, 1988, s. 431).

Satellitnavigation blev et alternativ til Loran-C med introduktionen af det såkaldte Navsat-system i 1962 (Clautice, 1978, s. 37). Systemet var ikke geostationært,

\footnotetext{
${ }^{7}$ Et Loran-C radiofyr er et radionavigationssystem, hvor egen position kan findes ved at måle på tidsforskellen mellem signalerne fra flere forskellige Loran-C radiofyr.

${ }^{8}$ Inertinavigation virker ved, at en computer ved hjælp af gyroskoper beregner, hvor langt og i hvilke retninger fartøjet har bevæget sig fra sit udgangspunkt, og fastslår på den baggrund fartøjets aktuelle position og er således ikke afhængig af kontakt med omverdenen.
} 
og position fix skulle times til et tidspunkt, hvor en satellit passerede henover ubåden i sin bane, der så skulle modtage signalet med en særlig antenne. Andre systemer tog gradvist over, og fra ca. 1974 blev Loran-C et overvejende civilt system (Wilkes \& Gleditsch, 1987, s. 209). Omega radiofyr installeredes i Norge i midten af 1960'erne med dækningsområde i Norskehavet (Skogrand, 1998, s. 15). Med Omega-systemet behøvede Polaris-ubåden ikke at komme helt så tæt på overfladen for position fix som med Loran-C. Tidlige udgaver af GPS systemet bliver gradvist det primære navigationssystem for ubådene fra 1978 (Refuto, 2011, s. 191).

Adgangen til Loran-C var i en periode den mest hensigtsmæssige måde at skaffe den nødvendige præcision for Polaris-ubåde på. Der var alternativer til at skaffe den samme præcision, men det var muligheder, der samtidigt også eksponerede ubåden over for modstandere. Man kan derfor med rette betegne Loran-C installationer for dominerende positioner, når man alene ser på deres betydning for position fix. Betydningen er imidlertid kortvarig. Efter etableringen af radiofyret på Eiði etableredes der således ret hurtigt alternativer og erstatninger for Loran-C til at levere position fix til Polaris-atomubådene. Det er således alene i en afgrænset periode i 1960'erne, at Loran-C var den mest hensigtsmæssige metode til at understøtte Polaris-ubådes præcision. Men var Færøerne en unik beliggenhed for Loran-C, der kun vanskeligt kunne erstattes med en anden beliggenhed? Den eksisterende litteratur tildeler Loran-C i Eiði særlig betydning med et argument om, at missilernes rækkevidde gjorde Polaris-ubådene afhængige af at operere i Norskehavet, samt at en beliggenhed på Færøerne gav Loran-C dækning her (Villaume 1995, s. 616-621; Olesen \& Villaume 2018, s. 303). De første Polaris-missilers rækkevidde var 1200 sømil (Refuto, 2011, s. 135). Polaris-ubådene var derfor afhængige af at operere i Norskehavet for at kunne række deres mål i Sovjetunionen. Polaris-missiler i versionen A3 bliver operative i 1964 med en rækkevidde på 2500 sømil (Refuto, 2011, s. 135; Mackenzie \& Spinardi, 1988, s. 439). De første Polaris-missiler, med den begrænsede rækkevidde på 1200 sømil, udfases allerede i 1965 (Refuto, 2011, s. 135). Polaris A3's rækkevidde gav ubådene mulighed for at operere i patruljeområder langt fra modstanderens antiubåds-enheder (MacKenzie \& Spinardi, 1988, s. 440-441).

Med udgangspunkt i udviklingen af Polaris-missilernes rækkevidde, så blev Loran-C radiofyret i Eiði's dækningsområde ikke vigtigere henover 1960'erne, sådan som dele af litteraturen ellers argumenterer for. De amerikanske Polarisubådes primære atlantiske operationsområde flyttedes tværtimod i midten af 1960'erne fra Norskehavet og til den nordvestlige del af Atlanterhavet. Dermed flyttedes operationsområdet væk fra det område, som radiofyret på Eiði oprindeligt skulle dække. Fra 1965 var Polaris-ubådene ikke længere afhængige af at skulle operere i det oprindelige dækningsområde, og placeringen på Eiði mistede dermed sin oprindelige betydning.

Samlet set kan man argumentere for, at Eiði var en militærgeografisk dominerende position, da den bliver etableret henset til sin betydning for Polaris-ubådene. Men to forhold gør, at denne status hurtigt forsvinder. For det første blev nye 
systemer (eksempelvis Omega radiofyr) fra midten af 1960'erne centrale i en amerikansk forestilling om, hvordan præcision kan opnås. For det andet gav den teknologiske udvikling (alternative systemer og missilernes rækkevidde) hurtigt mulighed for at flytte operationsområderne. Set i det perspektiv er radiofyret på Eiði interessant for amerikanerne fra beslutningen om at etablere Loran-C radiofyret i Eiði, til det tidspunkt, hvor amerikanerne erkender, at andre systemer og operationsområder er mere relevante. Dermed kan Eiði's betydning som dominerende geografisk position afgrænses til at være ganske få år i 1960'erne. Eiði var en unik placering, da Loran-C radiofyret etableredes. Omvendt var radiofyret et af 30 radiofyr, U.S. Coast Guard etablerede over en kort periode (Kulturstyrelsen, 2013, s. 169-171). Eiði var en af mange tilsvarende dominerende positioner rundtom i verden, der var nødvendige for Polaris-ubådenes operationerne og dermed dele af den amerikanske nukleare strategi. Eiði var således ikke unik i en større strategisk alliancesammenhæng.

Det andet argument om betydningen af Loran-C i Eiði i litteraturen bygger på den antagelse, at der var et allieret pres for stationering af mellemdistanceraketter på dansk jord, samt at Loran-C radiofyret kunne tillægges strategisk betydning svarende til stationering af mellemdistanceraketter. Diskussionen om mellemdistanceraketter har sin rod i en diskussion, som opstod i 1957, hvor USA og de europæiske NATOallierede diskuterede NATO's konventionelle underlegenhed og USA's atomare sikkerhedsgaranti (Weber, 1992). Den amerikanske chef for NATO's Europakommando (SACEUR) stillede i 1958 et forslag om en mobil raketstyrke (Weber, 1992, s. 661). Forslaget stillede krav om allieret deltagelse og finansiering, men et brev til nationerne fra SACEUR viser eksplicit, at der ikke var et krav til de europæiske allierede om en specifik geografisk placering af missilerne i den forbindelse, snarere tværtimod (NATO, 1962). Tesen i den eksisterende litteratur, om en sammenhæng mellem et krav om stationering af mellemdistanceraketter og etablering af Loran-C radiofyret, kan således afkræftes i tilgængelige NATO-kilder. Der var de facto ikke et konkret stationeringskrav, Danmark kunne afbøde med Loran-C radiofyret i Eiði. At SACEUR eksplicit afviser et stationeringskrav over for nationerne, indikerer omvendt, at det kunne have været en bekymring blandt allierede. Tesen kan derfor sagtens have rod i en intern dansk overvejelse i Udenrigsministeriet og Forsvarsministeriet.

Hvor der ikke kan findes belæg i NATO-kilderne for et eksplicit stationeringskrav, så kan Loran-C have haft en mere generel betydning i forhold til NATOmellemdistanceraketter. I forbindelse med debatten om mellemdistanceraketter stilledes der i 1960 forslag om en fælles NATO atomslagstyrke - Multilateral Force (MLF) - og præsident Kennedy tilbød i 1961 at stille fem Polaris-ubåde til rådighed for MLF med henblik på, at NATO bemandede og opererede dem på multinational basis (Boulton, 1972, s. 279). Danmark skulle potentielt levere finansiering og mandskab til MLF. ${ }^{9}$ MLF Polaris-ubåde skulle i givet fald have haft samme

\footnotetext{
${ }^{9}$ En dansk andel af besætningerne i MLF ubådene nævnes eksplicit som et eksempel under amerikanske senatshøringer om MLF (Boulton, 1972, s. 289).
} 
operationsområder som de amerikanske. Og dermed var Loran-C ikke kun interessant i et amerikansk perspektiv, men også i et europæisk NATO-perspektiv. Derned kan man ikke se Loran-C på Færøerne som et alternativ til dansk involvering i MLF. Set $\mathrm{i}$ et allianceperspektiv er det amerikanske tilbud om mellemdistanceraketter svar på et europæisk ønske om indflydelse på atomvåbnene (Weber, 1992, s. 660). Hvor Danmark aktivt undgik atomvåben på sit territorium, ønskede lande som eksempelvis Tyrkiet og Italien mellemdistanceraketter på deres territorium, og mellemdistanceraketter var derfor i høj grad et europæiske projekt (NATO, 1963). Mellemdistanceraketter handlede derfor mere om, hvordan USA imødekom et europæisk ønske om atomvåben, som Danmark ikke delte, snarere end om, hvordan Danmark skulle afbøde et amerikansk ønske ved at tilbyde en placering til et Loran-C radiofyr.

\section{Radarstationen på Sornfelli}

Den eksisterende litteratur beskriver også Radarstationen på Sornfelli som en installation, der var vigtig for Færøernes betydning, og den omtales primært som en NATO radarstation (Johansen, 1999, s. 40; Jensen, 2014a, s. 70). Den omtales også som en del af den amerikanske Distant Early Warning (DEW) kæde, herunder som det der i kilderne omtales som seaward extension (Johansen, 1999, s. 36; Olesen \& Villaume, 2018, s. 301). At se Sornfelli som en del af DEW giver potentielt Sornfelli strategisk betydning for USA i forhold til varsling om sovjetiske strategiske bombefly (Johansen, 1999, s. 40). Der er således i den eksisterende litteratur forskellige vinkler på, om Sornfelli var en radarstation i en amerikansk varslingskæde eller i en NATO-varslingskæde. Hvilken varslingskæde, radarstationen indgik i, er vigtig i forhold til, hvilke operationer stationen understøttede og dermed dens militærgeografiske betydning.

I amerikanske kilder om DEW-linjen fremgår Sornfelli ikke som en radarstation i DEW linjen (Ray, 1966). Seaward extension af DEW var en forlængelse af DEW linjen fra august 1961 til september 1965 med konstant tilstedeværelse af fire krigsskibe med radar og fire radarovervågningsfly i området mellem Grønland, Island og Skotland (Ray, 1966, s. 57-64). DEW var således forlænget ned i GIUK i en periode, men Sornfelli var ikke denne forlængelse. Ifølge NATO kilder bliver stationen opført i 1962 som en del af NATO's Air Defence Ground Environment (NADGE), der var en kæde af luftrumsovervågningsradarer og kontrolstationer, som udbredtes til hele NATO's ydergrænse mod Sovjetunionen - fra Norge til Tyrkiet - og som skulle varsle om taktiske angreb mod NATO styrker og territorium i Europa (NATO, 1960a). Sornfelli-stationen blev opført ved hjælp af NATO infrastrukturmidler som led i en prioriteret udbygning af NATO's varslingsnet, hvor stationen på Sornfelli er en af de stationer, der udvalgtes til at skulle opføres først (NATO, 1957; NATO, 1960a).

På samme tid som stationen på Sornfelli oprettedes, ændredes ansvarsfordelingen mellem NATO's chefer i Færøernes område, de såkaldte Terms of Reference (NATO, 1961a, 1961b). NATO's øverstkommanderende i Europa (SACEUR) 
overtog ansvaret for luftrummet over Færøerne, mens NATO's øverstkommanderende i Atlanterhavet (SACLANT) fastholdt det sømilitære ansvar omkring Færøerne. I 1963 kom stationen direkte ind i britisk indflydelsessfære, da den blev en del af en britisk luftoperationssektor (Jensen, 2004, s. 200). Radarstationen skal derfor ses i en europæisk NATO-sammenhæng fremfor i sammenhæng med amerikansk territorium.

Hvilke militære operationer skulle radarstationen på Sornfelli understøtte? Norskehavet blev i NATO frem mod 1980'erne et selvstændigt operationsområde for flerværnsoperationer, med betydning for forsvaret af selve Europa (Skogrand, 1998, s. 7-8). Det betyder, at man ikke kun skal se de militære operationer i Norskehavet i et sømilitært perspektiv i forbindelse med kampen om Atlanterhavet, men også i et luftmilitært perspektiv i forbindelse med kampen om Europa. NATO etablerede i slutningen af 1960'erne et lagdelt luftforsvar, herunder i GIUK, der involverede forskellige militære kapaciteter, herunder også forsvar mod taktiske flystyrker (Grove, 1989, s. 4-6). NATO anså lavtflyvende sømålsmissiler og krydsermissiler, anvendt sammen med en omfattende elektronisk krigsførelse, som de farligste konventionelle trusler (Dyndal, 2011, s. 580; NATO, 1969b). Ubådsbekæmpelsen var omdrejningspunktet, men NATO var også nødt til at kunne kæmpe mod sovjetiske fly- og overfladeenheder for at have den fornødne frihed til at kunne bekæmpe ubåde.

Radarstationen opdateredes i starten af 1980'erne, herunder med en ny radar i 1983. ${ }^{10}$ Radarstationen fik endvidere evnen til at modtage og videresende radarbilledet fra NATO's nye radarovervågningsfly (Østerud, 2014, s. 123; NATO, 1978). Dermed blev radarstationen bedre til at operere i et operationsmiljø med elektronisk krigsførelse. Data-forbindelsen til overvågningsfly gav mulighed for at se lavtgående fly og missiler, der ellers kunne gemme sig under radarhorisonten. Med moderniseringen knyttedes radarstationen tættere til forsvaret af Storbritannien. Briterne havde deres eget kommando- og kontrolsystem, der moderniseres i slutningen af 1970'erne med fokus på angreb kommende fra nordvest for Skotland (Campell, 1980, s. 45).

Når man inddrager NATO kilderne, kan man afvise den strategiske betydning i varslingen af USA mod strategiske bombefly, som dele af den eksisterende litteratur tildeler Sornfelli. De to kæder, DEW og NADGE, var rettet mod hver sin fjendtlige hensigt; henholdsvis angreb med langtrækkende bombefly mod Nordamerika og (overvejende) taktiske angreb mod NATO's styrker og territorium i Europa. Når man ser på, om Sornfelli militærgeografisk var en dominerende position, skal man derfor se på, om det var en hensigtsmæssig og unik position til at understøtte det lagdelte luftforsvar i NATO's europæiske ansvarsområde. NATO's prioritering af Sornfelli ved etableringen af NAGDE kæden indikerer, at Sornfelli var en hensigtsmæssig placering, der kunne understøtte højtprioriterede taktiske operationer. Den

\footnotetext{
${ }^{10}$ NATO fællesfinansieret radar. Der blev opstillet en radar af samme type på Bornholm (Westergaard, 2008).
} 
rummede særlige muligheder $\mathrm{i}$ et britisk perspektiv, hvor den virkede som en fremskudt post i det britiske luftforsvar, der kunne give tidlig varsling om lavtflyvende missiler og fly på vej mod Storbritannien. Sornfelli kan således betegnes som en dominerende geografisk position i det britiske luftforsvar under Den Kolde Krig. Sornfelli havde en unik position i et britisk fremfor i et NATO perspektiv, hvilket er et underrepræsenteret perspektiv i den eksisterende litteratur, der har fokus på USA. Sornfelli var ikke central i forhold til sovjetiske bombefly med strategiske atomvåben rettet mod USA, sådan som det fremgår af dele af den eksisterende litteratur, men var en vigtig brik i den britiske luftrumsovervågning mod nord. Sornfelli var derfor ikke en strategisk dominerende geografisk position, men var det på det taktiske niveau. Sornfelli var en af mange fremskudte radarstationer ned igennem Europa. En lang række placeringer for NADGE-radarstationer kan i lighed med Sornfelli betegnes som geografisk dominerende taktiske positioner, med henblik på til at etablere et sammenhængende radarbillede i hele NATO's Europæiske område. Sornfelli var derfor en vigtig taktisk installation, men ikke unik set i et NATO perspektiv.

\section{Troposfære kommunikationssystemer}

Kommunikationsstationer i NATO's Forward Scatter system og North Atlantic Radio System (NARS) på Færøerne beskrives i litteraturen som systemer, der gav Færøerne en strategisk betydning (Johansen, 1999, s. 43; Jensen, 2004, s. 201-202). De omtalte systemer er såkaldte troposfære kommunikationssystemer. ${ }^{11}$ Forward Scatter systemet etableredes primært til at understøtte NATO's europæiske luftforsvarssystem - NADGE (NATO, 1956d). Forward scatter systemets betydning hang derfor sammen med radaren på Sornfelli og NARS stationen var derfor det eneste troposcattersystem, der kunne betinge en selvstændig betydning i Færøernes militærgeografi.

NARS var en af flere teknologier, der benyttedes under Den Kolde Krig til at formidle den strategiske varsling om atomangreb. NARS' betydning hang derfor sammen med den periode, hvor NARS var den primære teknologi til formidling af denne varsling. NARS stationen på Færøerne etableredes i starten af 1960'erne og eksisterede frem til 1988 (Jensen, 2004, s. 154). NARS var en række relæstationer, der etableredes for at forbinde Ballistic Missile Early Warning (BMEW) sensoren i Fylingsdale, Storbritannien, med kommandocentraler i USA for at varsle om sovjetiske angreb med interkontinentale atommissiler (Kulturstyrelsen, 2013, s. 176). NARS stationens betydning skal derfor ses i sammenhæng med betydningen af BMEW Fylingsdale's varsling. BMEW Fylingsdale var og er én af tre ${ }^{12}$ stationer, der kan varsle om interkontinentale atommissiler på vej fra Rusland til USA (Spinardi, 2007). Set i et amerikansk strategisk perspektiv var Fylingsdale en vigtig installation,

\footnotetext{
${ }^{11}$ Kommunikationssystemer der udnytter, at radiosignaler kan reflekteres i troposfæren.

${ }^{12} \mathrm{De}$ to andre var og er placeret i henholdsvis Alaska og på Thulebasen i Grønland.
} 
men dog langt fra så betydende som de tilsvarende radarer i Alaska og Thule, og varslingen fra Fylingsdale sås som et supplement til de to andre sensorer (Spinardi, 2007).

NARS blev gradvist erstattet med blandt andet satellitkommunikation under Den Kolde Krig. USA's kommunikationssatellitter udvikledes hurtigt i flere trin; Initial Defense Communication Satellite Program etableredes 1966-1968 (Spires \& Sturdent, 1999, s. 67-68), Defense Satellite Communication System etableres i 1970erne og er fuldt operativt i starten af 1980erne (Spires \& Sturdent, 1997, s. 70-72). Samtidigt begyndte USA at anvende civile satellitter og andre forbindelser til sine strategiske kommando- og kontrolfunktioner, for at kunne imødekomme en stigende efterspørgsel (Spires \& Sturdent, 1997). Isoleret set havde NARSstationen på Færøerne en dominerende geografisk position i den periode, hvor teknologien var væsentlig for videreformidlingen af BMEW varsling, men også på dette område udviklede teknologien sig hurtigt, og USA opbyggede et vidt forgrenet net af kommunikationslinjer med en stadig større redundans. Der var derfor ikke så meget tale om et system, som erstatter et andet, som at der lagdes stadigt flere lag på kommunikationsinfrastrukturen. NARS ophørte derfor med at have væsentlig betydning for USA lang tid før, stationen lukkedes. NARS-stationen kan derfor betegnes som en dominerende geografisk position i løbet af 1960'erne, hvorefter dens betydning hurtigt aftog. Uden stationen på Færøerne var der et hul i NARS-kæden mellem BMEW Fylingsdale og USA. Stationen understøttede således den amerikanske varsling fra et hensigtsmæssigt sted, der var en unik placering, netop fordi den samlede kæde ikke ville have fungeret uden stationen på Færøerne, men samtidigt var det også en af flere unikke placeringer, der skulle til for at etablere en kæde. Færøerne var ikke ene om at have dominerende geografisk NARS placering.

\section{Færøernes militærgeografiske betydning under Den Kolde Krig som forståelsesramme}

Gennemgangen af litteraturen om Færøernes militær betydning under Den Kolde Krig viser, at Færøerne hidtil har været tillagt stor militær betydning under Den Kolde Krig og dermed stor betydning i forholdet mellem USA og Kongeriget Danmark. Gennemgangen af de forskellige forhold, der kunne betinge en sådan betydning, viser imidlertid, at Færøerne generelt ikke var en militærgeografisk dominerende position for USA under Den Kolde Krig. Der var dog en kort periode i starten og midten af 1960'erne, hvor den teknologiske udvikling kortvarigt gav Færøerne en rolle i USA's atomstrategi, i lighed med en lang række tilsvarende positioner i andre lande.

Færøerne kan siges at have været en dominerende militærgeografisk position i starten og midten af 1960 'erne i kraft af Loran-C radiofyret og NARS-troposcatterstationen. Men det skal i den forbindelse bemærkes, at de to installationer på Færøerne var en del af en lang række tilsvarende installationer hos NATO-allierede, 
som ligeledes understøttede strategisk vigtige militære operationer. Det er derfor ikke særligt sandsynligt, at Færøerne gav en speciel fordel i alliancesammenhæng, sådan som det ellers hævdes i dele af den eksisterende litteratur. Den Kolde Krig og våbenkapløbet medførte et stort og skiftende behov for den slags installationer. Selv om en placering på Færøerne var essentiel, kan det samme siges om talrige installationer hos andre NATO-allierede.

I forhold til en fremtidig forståelse af Færøernes betydning er spørgsmålet, om den nye spænding mellem Rusland og USA samt NATO vil give Færøerne en militær betydning tilsvarende den, som Færøerne havde under Den Kolde Krig. Militærgeografien er kontekstuel og afhængig af parternes muligheder og opfattelse af muligheder (Gray, 2012, s. 301-302). Man vil derfor ikke automatisk kunne gå ud fra, at en ny spændingsperiode i Nordatlanten vil betyde en gentagelse af tidligere militær betydning. Eksempelvis vil Kinas interesse i Arktis kunne give andre opfattelser af hensigter og muligheder, end tilfældet var under Den Kolde Krig. Gennemgangen af Færøernes betydning under Den Kolde Krig viste, at selv om Færøerne lå i et område med stor strategisk betydning (GIUK), så modsvaredes dette ikke fuldt ud i militær betydning, fordi Færøerne ikke var velegnet til at understøtte de konkrete militære operationer. At Færøerne ikke automatisk fik stor militær betydning alene i kraft af sin beliggenhed under Den Kolde Krig, er også en vigtig pointe i forhold til den nuværende debat om Færøernes fremtidige betydning.

Når man ser på fremtidig betydning, skal man derfor se på den konkrete militære nytte. Det, der opfattes som Ruslands stadig mere aggressive adfærd, har givet NATO et fornyet fokus på Nordatlanten, og USA, Storbritannien og Norge er i gang med at opgradere baser og maritime patruljefly og har indgået en strategisk samarbejdsaftale herom (Tamnes, 2016; Bauke, 2018; s. 26-29; Hamre \& Conley, 2016; DoD, 2017; DoD, 2019). Skal man forstå Færøernes fremtidige militære betydning, skal man derfor forstå, hvordan Færøerne kan passe ind i og understøtte disse og kommende operationsmønstre, herunder hvad en placering på Færøerne kan tilføre sammenlignet med tilsvarende placeringer i eksempelvis Island og Skotland.

I forhold til den eksisterende litteraturs fremstilling af Færøernes betydning er det tidsmæssige aspekt interessant. Den teknologiske udvikling er også med til at forandre militærgeografien over tid. Forskellige tekniske installationer gav Færøerne en betydning i en afgrænset tidsperiode under Den Kolde Krig, hvilket afspejler et våbenkapløb mellem supermagterne, og teknologien udviklede sig hurtigt (eksempelvis at Polaris-missilers rækkevidde fordobledes på fire år). I forhold til en fremtidig forståelsesramme skal man således tænke ind, at fremtidig stormagtsrivalisering også kan medføre skiftende fokus på teknologier. Færøernes militære betydning i en ny sikkerhedspolitisk orden er ikke nødvendigvis blivende. Den nye sikkerhedspolitiske rivalisering kan medføre, at Færøerne får en mere omskiftelig militær betydning.

Gennemgangen af Færøernes betydning under Den Kolde Krig afdækkede, at den eksisterende litteratur har tildelt Færøerne en større rolle i forhold USA, end landet reelt havde. Det er interessant i en nutidig sammenhæng, fordi fortællingen 
om Færøerne betydning for USA stadig har en plads. Eksempelvis var det et færøsk argument i sagen om en kinesisk udbyder af 5G mobilnetværk, at Færøernes strategiske placering mellem Europa og Arktis var årsagen til, at USA var særlig opmærksom på, hvem der skulle være 5G teleudbyder på Færøerne (Breum, 2019). USA's pres skal snarere ses i sammenhæng med et generelt pres på allierede for ikke at benytte den kinesiske teleudbyder (Breum, 2019). Men fortællingen om Færøerne som vigtig for USA er tilsyneladende fortsat en forståelsesramme, henset til at den blev genfortalt i forbindelse med den aktuelle sag. Derfor er den eksisterende litteraturs fremstilling ikke ligegyldig.

Hvor den eksisterende litteratur fokuserer på Færøernes betydning for USA, gives Færøernes betydning for Storbritannien under Den Kolde Krig ikke megen opmærksomhed. Sornfelli-radaren ses i et amerikansk perspektiv (blandt andet i Johansen, 1999), men indgik som en integreret del af det britiske luftforsvar. Fraværet af Storbritanniens betydning kan hænge sammen med, at fokus i litteraturen har været på de færøsk-danske forhold, og de fordele Danmark kunne opnå hos USA. I forhold til en forståelse af fremtidig militær betydning kan der derfor være grund til også at fokusere på Færøernes betydning for andre allierede og ikke kun på Færøernes militære betydning for USA. I forlængelse af det kan det bemærkes, at Loran-C radiofyret, som tillægges stor betydning i den eksisterende litteratur, fortsætter som et civilt system efter Den Kolde Krig og finansieres af Frankrig fra 2006, frem til det lukkes i 2015 (Søfartsstyrelsen, 2015). En enkelt færøsk kilde noterer sig, at Frankrig overtog ansvaret (Jákupsstovu \& Berg, 2012). Men der er i den forbindelse ikke overvejelser om Frankrigs formål eller implikationerne for Færøernes betydning. Strategisk betydning ses fortsat alene i forhold til USA. Selvom Færøerne måske ikke har strategisk militær betydning for supermagten, kan der være andre aktører med en interesse for Færøerne, der fylder relativt mere i disse allieredes perspektiv.

Gennemgangen af Færøerne som baseområde under Den Kolde Krig viste, at Færøerne ikke nødvendigvis fik stor militær betydning, selvom Færøerne lå i et militært vigtigt farvand. Når man anvender det som forståelsesramme for at se på fremtidig betydning, kan der være god grund til at skille den strategiske betydning, som Færøerne får i kraft af udviklingen og klimaforandringerne i Arktis, fra den militære betydning, Færøerne måtte få som følge af den øgede stormagtsrivalisering i Nordatlanten. En placering i et område, der får større geopolitisk betydning, er ikke nødvendigvis det samme som, at denne placering automatisk får større militær betydning.

Den militære betydning af Færøerne har været set som noget man kunne veksle til økonomiske fordele og uafhængighed for Danmark (Brøndum, 2000). Men man kan i den forbindelse stille sig selv spørgsmålet, om stor militærgeografisk betydning alene er en fordel. Fravær af militær betydning, og dermed fravær af relaterede stormagtsinteresser, kunne også være en mulighed for, at Færøerne kan fortsætte sin selvstændige politik med bilaterale relationer inden for en række områder. I perioden 
efter Den Kolde Krig befandt Færøerne sig i et lavspændingsområde med mulighed for at forfølge en selvstændig strategi til at udnytte sin placering i forhold til Arktis (Bailes \& Jákupsstovu, 2013; Logmansskrivstovan, 2013). Genkomsten af geopolitikken i Arktis og Nordatlanten kan udfordre muligheden for at forfølge en selvstændig færøsk strategi. Den føromtalte strid om en kinesisk teleudbyder på Færøerne er et eksempel på, at stadig flere områder bliver inddraget i stormagternes rivalisering. I et sådant sikkerhedspolitisk miljø kan det være hensigtsmæssigt ikke at tiltrække sig unødig stormagtsinteresse. Fravær af militær betydning kan derfor være en tilsvarende vigtig erkendelse som stor militær betydning, henset til de muligheder fravær af militær betydning også giver Færøerne og dermed Kongeriget Danmark. Samlet set kan der være god grund til at undersøge fremtidig militær betydning konkret og undgå automatiske antagelser om militær betydning alene baseret på overordnede geopolitiske forandringer og den historiske forståelse.

Note: Jeg vil gerne takke Jon Rahbek-Clemmensen for kommentarer og spørgsmål undervejs i udarbejdelsen af artiklen. Fejl og udeladelser er mine egne.

\section{Om forfatterne}

Esben Salling Larsen er miltæranalytiker ved Center For Værnsfælles Operationer under Forsvarsakademiet i København.

\section{Referanser}

Bailes, A. J. K. \& Jákupsstovu, B. (2013). The Faroe Islands and the Arctic: Genesis of a strategy. Icelandic Review of Politics and Administration, 8(4), 531-548. https://doi.org/10.13177/irpa.a.2013.9.2.14

Ball, D. J. (1977). The Counterforce Potential of American SLBM Systems. Fournal of Peace Research, 14(1), 23-40. https://doi.org/1177/002234337701400102

Bauke, N. (2018, 10. januar). Restoration of US air base in Iceland does not mean troops will follow Navy says. Navy Times. Hentet fra https://www.navytimes.com/news/2018/01/10/restoration-of-us-air-base-iniceland-does-not-mean-troops-will-follow-navy-says/

Benediktsson, E. (2011). At crossroads - Iceland's defense and security relations 1940-2011. Strategic Studies Institute. Hentet fra https:/ssi.armywarcollege.edu/index.cfm/articles/Icelands-Defense-and-SecurityRelations-1940-2011/2011/8/18

Bertelsen, R. G. (2019). Historisk læring som struktur for dialog om det fremtidige forhold mellem Danmark og Nordatlanten. Politica - Tidsskrift for politisk videnskab, 51(4), 401-422.

Boulton, J. W. (1972). NATO and the MLF. Fournal of Contemporary History, 7(3), 275-294. https://doi. org/10.1177/002200947200700317

Breum, M. (2019, 18. december). Brexit, Huawei og Trump skærper Grønlands og Færøernes pres på Mette Frederiksen. Altinget. Hentet fra https:/www.altinget.dk/arktis/artikel/martin-breum-brexit-huawei-ogtrump-skaerper-groenlands-og-faeroeernes-pres-paa-mette-frederiksen

Brøndum, C. (2000, 15. juni). Ekspert: Færøerne ikke vigtig for NATO. Berlingske Tidende. Hentet fra https:// www.berlingske.dk/samfund/ekspert-faeroeerne-ikke-vigtig-for-nato

Campell, D. (1980, 11. januar). Britain's new air defence programme starts: Will it be any better than the last. New Statesman.

Clautice, W. G. (1978). Submarine navigation. Fournal of Navigation, 25(1). https://doi.org/10.1002/j. 2161-4296.1978.tb01312.x

Collins, J. M. (1998). Military geography for professionals and the public. Washington, DC: National Defense University Press. 


\section{Esben Salling Larsen}

Dansk Udenrigspolitisk Institut (DUPI). (1997). Grønland under Den Kolde Krig: Dansk og amerikansk sikkerhedspolitik 1945-68. Dansk Udenrigspolitisk Institut.

Dansk Institut for Internationale Studer (DIIS). (2005). Danmark Den Kolde Krig - den sikkerhedspolitiske situation 1949-1991, bind 2. Dansk Institut for Internationale Studier.

Department of Defense (DOD). (2017). The United States, the United Kingdom, and Norway trilateral declaration of intent on maritime security in the North Atlantic, June 29, 2017. Release No: NR-248-17. Hentet fra https:/dod.defense.gov/News/News-Releases/News-Release-View/Article/1233068/the-united-statesthe-united-kingdom-and-norway-trilateral-declaration-of-inten/

Department of Defense (DOD). (2019). Report to Congress Department of Defense Arctic Strategy. Office of the Under Secretary of Defense for Policy. Juni 2019. Hentet fra https://media.defense.gov/2019/ Jun/06/2002141657/-1/-1/1/2019-DOD-ARCTIC-STRATEGY.PDF

Dyndal, G. L. (2011). How the High North became central in NATO strategy: Revelations from the NATO archives. Fournal of Strategic Studies, 34(4), 557-585. https://doi.org/10.1080/01402390.2011.561094

Faurby, I. \& Petersen, N. (1988). The Far North in Danish security policy. Paper for panel on "Resource and Security Issues of the Far North", ISA 29th Annual Convention, St. Louis, March 29-April 2, 1988.

Gray, C. S. (2012). Geopolitics and deterrence. Comparative Strategy, 31(4), 295-321. https://doi.org/10.1080 /01495933.2012.711116

Grygiel, J. J. (2005). The dilemmas of US maritime supremacy in the early Cold War. Fournal of Strategic Studies, 28(2), 187-216. https://doi.org/10.1080/01402390500088270

Grove, E. (1989). NATO's defence of the North. Brassey's Atlantic Commentaries No.1.

Hamre J. J. \& Conley, H. A. (2016). The centrality of the North Atlantic to NATO and US strategic interests. Whitehall Papers, 87(1), 43-58. https://doi.org/10.1080/02681307.2016.1291020

Ingimundarson, V. (1999). The struggle for Western integration: Iceland, the United States and NATO during the first Cold War. Forsvarsstudier 3/1999, Institutt for forsvarsstudier.

Ingimundarson, V. (2003). A western cold war: The crisis in Iceland's relations with Britain, the United States, and NATO, 1971-74. Diplomacy E Statecraft, 14(4), 94-136. https://doi.org/10.1080/09592290312331 295694

Jácubsstovu, B. \& Berg, R. (2012). The Faroe Islands' security policy in a process of devolution. Stjórnmál E Stjórnsýsla, 8(2), 413-430.

Jácubsstovu, B. \& Berg, R. (2014). Færøysk sikkerhetspolitikk. I G. Hovgaard, B. Jácubsstovu \& A. Sølvarå (Red.), Vestnorden - nye roller $i$ det internationale samfund. Fróeðskapur, Thorshavn.

Jensen, B. (2004). Føroyar i kalda krígnum - Ferøerne under Den Kolde Krig. Tórshavn.

Jensen, B. (2014a). Ulve, får og vogtere 2: Den Kolde Krig i Danmark 1945-1991. Gyldendal.

Jensen, B. (2014b). Militcere institutioner og anleg på Fcerøerne under Den Kolde Krig. Tillæg til Bent Jensens Ulve, får og vogtere: Den Kolde Krig i Danmark 1945-1991.

Johansen, S. T. F. (1999). Ferøerne under Den Kolde Krig: De Militer Installationer. Føroya Landsstýri.

Johansen, S. T. F. (2011). Færøerne: Kampen om indflydelse. I J. T. Lauridsen, R. Mariager, T. B. Olesen \& P. Villaume (Red.), Den Kolde Krig og Danmark, (s. 295-298). Gads Leksikon.

Keohane, R. O. (1971). The big influence of small allies. Foreign Policy, 2, 161-182. https://doi.org/10.2307/ 1147864

Kochis, D. \& Slattery, B. (2016). Iceland: Outsized importance for transatlantic security. Backgrounder No. 3121 , June 21, 2016. The Heritage Foundation. Hentet 5. august fra https:/www.heritage.org/global-politics/ report/iceland-outsized-importance-transatlantic-security

Krog, A. (2019, 21. november). USA advarer Færøerne mod Huawei. Altinget. Hentet fra https://www.altinget. $\mathrm{dk} /$ arktis/artikel/usa-advarer-faeroeerne-mod-huawei

Kulturstyrelsen. (2013). Kold krig 2013 - 33 fortcellinger om Den Kolde Krigs bygninger og anleg $i$ Danmark, Ferøerne og Grønland. Hentet fra https://issuu.com/kunststyrelsen/docs/kold_krig_2013/176

Logmansskrivstovan. (2013). The Faroe Islands - a nation in the Arctic. The Prime Minister's Office, The Foreign Service. Hentet 5. august fra https://ms.cdn.fo/media/10243/f\%C3\%B8royar-eitt-land-\%C3\%AD-arktisuk-web.pdf?s=jggeB2qre-4xB5sMlrqpjQdbTrg=

MacKenzie, D. \& Spinardi, G. (1988). The shaping of nuclear weapon system technology: US fleet ballistic missile guidance and navigation. I From Polaris to Poseidon. Social Studies of Science, 18(3), 419-463. https://doi.org/10.1177/030631288018003002

Olesen, T. B. (2008). Under the national paradigm: Cold War studies and Cold War politics in post-Cold War Norden. Cold War History, 8(2), 189-211. https://doi.org/10.1080/14682740802018686

Olesen, T. B. \& Villaume, P. (2018). Dansk Udenrigspolitiks Historie bind 5: I blokopdelingens tegn 1945-1972. Gyldendal. 
Plümper, T. \& Neumayer, E. (2015). Free-riding in alliances: Testing an old theory with a new method. Conflict Management and Peace Science, 32(3), 247-268. https://doi.org/10.1177/0738894214522916

Ray, T.W. (1966). A history of the DEW line 1946-1964. Air Defence Command Historical Study No. 31. United States Air Force.

Refuto, G. J. (2011). Evolution of the US sea-based nuclear missile deterrent. Xlibris cooperation.

Rigsombudsmanden på Færøerne. (2020). Indberetning nr. 1/2020. Tórshavn, den 4. februar 2020. Hentet fra https:/www.ft.dk/samling/20191/almdel/F\%C3\%86U/bilag/13/2145574/index.htm

Ringsmose, J. (2010). NATO burden-sharing redux: Continuity and change after the Cold War. Contemporary Security Policy, 31(2), 319-338. https://doi.org/10.1080/13523260.2010.491391

Skogrand, K. (1998). Bodø og forsvaret av Nord-Norge 1945-1967. Brennpunkt: Kald krig, nordområder og Storstrategi IFS Info 5/1998, 7-18. Institutt for Forsvarsstudier.

Snyder, G. (1984). The security dilemma in Alliance politics. World Politics 36, 461-95. https://doi. $\operatorname{org} / 10.2307 / 2010183$

Spinardi, G. (2007). Golf balls on the moor: Building the Fylingdales ballistic missile early warning system. Contemporary British History, 21(1), 87-110. https://doi.org/10.1080/13619460600785879

Spires, D. N. \& Sturdevant, R. W. (1997). From Advent to Milstar - the U.S. Air Force and the challenges of military satellite. I A. J. Butrica (Red.), Beyound the ionosphere - fifty years of satellite communication. The NASA History Series. Government printing Office.

Statsministeriet. (2020). Møde mellem statsministeren, lagmanden og formanden for Naalakkersuisut. Pressemeddelelse 7. januar 2020. Hentet fra http://www.stm.dk/_p_14895.html

Søfartsstyrelsen. (2015). Ejde Loranstation på Fcrøerne lukkes. 3. december 2015. Hentet 5. august fra https:// www.soefartsstyrelsen.dk/Presse/Nyheder/Sider/Ejde-Loranstation-p\%C3\%A5-F\%C3\%A6r\%C3\% B8erne-slukkes-31.-december-2015.aspx

Tamnes, R. (1991). The United States and the Cold War in the High North. Ad Notam.

Tamnes, R. (2016). The significance of the North Atlantic and the Norwegian contribution. Whitehall Papers, 87(1), 8-31. https://doi.org/10.1080/02681307.2016.1291018

Villaume, P. (1995). Allieret med forbehold, Danmark, NATO og Den Kolde Krig: En studie i dansk sikkerhedspolitik 1949-1961. Forlaget Eirene, København.

Walt, S. (1985). Alliance formation and the balance of world power. International Security, 9(4), 3-43. https:// doi.org/10.2307/2538540

Weber, S. (1992). Shaping the postwar balance of power - multilateralism in NATO. International Organisations, 46(3), s.633-680. https://doi.org/10.1017/S0020818300027855

Wilkes, O. \& Gleditsch, N. P. (1987). Loran-C and Omega: A study of the military importance of radio navigation aids. Norwegian University Press.

Woodward, R. (2016). Military geography. I R. A. Marston et al. (Red.), International encyclopedia of geography: People, the earth, environment and technology. https://doi.org/10.1002/9781118786352.wbieg0280

Østerud, Ø. (2014). Fremtidens sikkerhetspolitikk i et vestnordisk perspektiv. I G. Hovgaard, B. Jácubsstovu \& A. Sølvarå (Red.), Vestnorden - nye roller $i$ det internationale samfund (s. 122-129). Fróeðskapur, Thorshavn.

Westergaard, F. (2008). Fra ASTA til SKYLIGHT og GOTHAM - En beretning om Flyvevåbnets kontrol-og varslingstjeneste 1951-2007. Flyvevåbnets Historiske Samling, Karup.

\section{NATO online arkiv}

NATO. (1953). SGM-1666-3 Memorandum for the Standing Group - Meeting of Chairman, Standing Group, with Danish Chief of Defense, 31 fuly 1953. Hentet 5. august 2019 fra http://archives.nato.int/meeting-ofchairman-of-standing-group-with-danish-chief-of-defence-31-july-1953

NATO. (1956a). DEF905665 (Jun 56) from SGN. Subject is The Strategic Consequences of the Withdrawal of the United States Forces from Iceland. Hentet 5. august 2019 fra http://archives.nato.int/strategic-consequencesof-withdrawal-of-us-forces-from-iceland-6

NATO. (1956b). M.C.63 (final) A Report by the Military Committee on The Strategic Consequences of the Withdrawal of United States Forces from Iceland. Hentet 5. august 2019 fra http://archives.nato.int/strategicconsequences-of-withdrawal-of-united-states-forces-from-iceland-5

NATO. (1956c). DEF906014 (Jul 5) from SGN. Msg STAND 1574 from SGN reference STAND 1563. Hentet 5. august 2019 fra http://archives.nato.int/uploads/r/null/1/3/136581/STAND_1574_BIL_PDP.pdf

NATO. (1956d). M.C.59 Report by the Military Committee to the North Atlantic Council on the Requirement for a Reliable and Secure Allied Command Europe Signal Communication System. Hentet 5. august 2019 fra http:// 


\section{Esben Salling Larsen}

archives.nato.int/requirement-for-reliable-and-secure-allied-command-europe-signal-communicationssystem

NATO. (1957). C-M(57)48 The 1957 (Slice VII) NATO Common Infrastructure Programme. Hentet 5. August $2019 \mathrm{fra} \mathrm{http://archives.nato.int/1957-slice-08-nato-common-infrastructure-programme}$

NATO. (1960a). PO/60/433 Technical Aspects of Air Defence. Hentet 5. august 2019 fra http://archives.nato.int/ technical-aspects-of-air-defence

NATO. (1960b). MC92 A Report by the Military Committee to the North Atlantic Council on an Overall Evaluation of the MC 70 Country Studies. Hentet 5. august 2019 fra http://archives.nato.int/an-overallevaluation-of-the-mc-70-country-studies

NATO. (1961a). MC-42-61 Amendment of SACEUR's Terms of Reference as Laid Dopwn in MC53 (Final). Hentet 5. august 2019 fra http://archives.nato.int/amendment-of-saceurs-terms-of-reference-as-laid-downin-mc-053-final-3

NATO. (1961b). MC-77-61 Amendment of SACEUR's Terms of Reference as Laid Dopwn in MC53 (Final). Hentet 5. august 2019 fra http://archives.nato.int/amendment-of-saceurs-terms-of-reference-as-laiddown-in-mc-053-final-4

NATO. (1962). MC99 (draft) A Report by the Standing Group to the Military Committee on Military Aspects of the Integration of MRBM's Into NATO. Hentet 5. august 2019 fra http://archives.nato.int/military-aspects-ofthe-integration-of-mrbms-into-nato

NATO. (1963). LOM 28/63 NATO Consultation on Replacing IRBM's with Polaris Submarines in the Mediterranean. Hentet 5. august 2019 fra http://archives.nato.int/nato-consultation-on-replacing-irbmswith-polaris-submarines-in-the-mediterranean

NATO. (1969a). MC 48/3 (Final) Final Decision On MC48/3 Measures to Implement the Strategic Concept for the Defence of the NATO Area. Hentet 5. august 2019 fra Link: https://www.nato.int/docu/stratdoc/eng/ a691208a.pdf

NATO. (1969b). IMSWM-196-69 Memorandum for the members of the Military Committee - Relative Strategies and Capabilities of NATO and the Soviet Bloc. Hentet 5. august 2019 fra Link: http://archives.nato.int/ relative-maritime-strategies-and-capabilities-of-nato-and-the-soviet-bloc

NATO. (1978). NATO AWACS, NATO Information Service. Hentet 5. august 2019 fra http://archives.nato. int/nato-awacs

\section{Abstract in English \\ The Faroe Islands' Military Geographic Significance to the USA and NATO} In the literature on Denmark during the Cold War and on Faroese security policy, one finds the argument that military installations gave the Faroe Islands a strategic importance in NATO during the Cold War. This article has analysed the significance of the Faroe Islands from a military geographic perspective, has used a broader range of sources, and has compared the Faroe Islands with similar locations. It can be concluded that the Faroe Islands have been a dominant geographical position for a short period in the 1960s. Contrary to the prevailing notion in existing Danish and Faroese literature, the Faroe Islands were not a significant base area during the Cold War and the installations were not unique, but were indicative of many similar installations. The military importance of the Faroe Islands during the Cold War can be seen as a framework for understanding the future importance. Future analysis should look into on how the Faroe Islands' location can actually support military operations and should be aware that a new security situation does not necessarily give areas such as the Faroe Islands a permanent significance, but can easily result in a frequently changing significance.

Keywords: military geography $\cdot$ Faroe Islands $\cdot$ Cold War $\cdot$ NATO $\cdot$ North Atlantic 